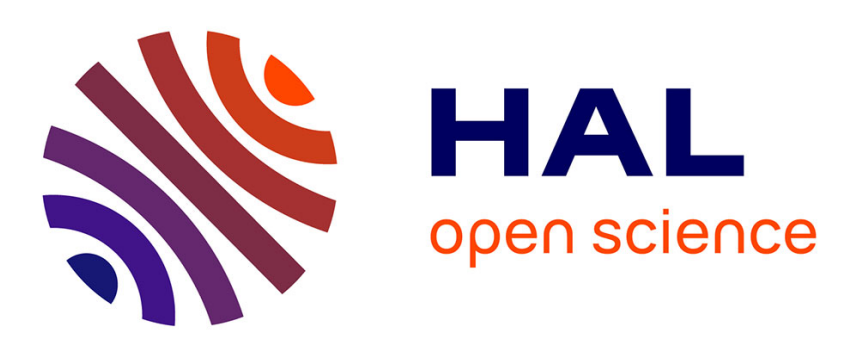

\title{
Maintenance and creation of roles during socialization processes in entrepreneurial small firms: An institutional work perspective
}

Emilie Bargues, Bertrand Valiorgue

\section{- To cite this version:}

Emilie Bargues, Bertrand Valiorgue. Maintenance and creation of roles during socialization processes in entrepreneurial small firms: An institutional work perspective. M@n@gement, 2019, 22, pp.30 - 55. halshs-02477520

\author{
HAL Id: halshs-02477520 \\ https://shs.hal.science/halshs-02477520
}

Submitted on 13 Feb 2020

HAL is a multi-disciplinary open access archive for the deposit and dissemination of scientific research documents, whether they are published or not. The documents may come from teaching and research institutions in France or abroad, or from public or private research centers.
L'archive ouverte pluridisciplinaire HAL, est destinée au dépôt et à la diffusion de documents scientifiques de niveau recherche, publiés ou non, émanant des établissements d'enseignement et de recherche français ou étrangers, des laboratoires publics ou privés. 


\title{
Maintenance and creation of roles during socialization processes in entrepreneurial small firms: An institutional work perspective
}

\author{
Emilie Bargues • Bertrand Valiorgue
}

Accepted by former co-editor in chief Laure Cabantous

\begin{abstract}
Entrepreneurial small firms (ESFs) are characterized by a permanent dynamic of innovation not only regarding their commercial offers, but also their organizational processes. Potentially, newcomers play a key role in the maintenance of this innovation dynamic, but there is a lack of knowledge regarding their socialization. In this research, we develop an understanding of socialization processes in ESFs by taking an institutional work perspective. Through a qualitative, longitudinal and inductive research design based on two case studies, we make several contributions. First, we identify different socialization activities enforced jointly and separately by newcomers and insiders. Second, we explain the dynamics of these activities with the achievement of two socialization outcomes: maintenance of institutionalized roles and the creation of new ones. Our results enrich the organizational socialization literature by introducing a new field of enquiry and by showing that role creation can be a major distal outcome of socialization processes. We also develop new perspectives on institutional work by demonstrating the importance of newcomers and the dimensions of agency at play during socialization processes.
\end{abstract}

Keywords: entrepreneurial small firms, newcomers, socialization processes, institutional work, role maintenance and creation

\section{INTRODUCTION}

Socialization of newcomers is a critical issue for the stability and performance of many organizations (Ellis, Bauer \& Erdogan, 2015; Wanberg, 2012), in addition to being more critical for entrepreneurial small firms (ESFs) (Atkinson \& Storey, 2016). Such firms are characterized by creativity and a permanent dynamic of innovation not only regarding their organizational processes, but also their commercial products or services through exploration and exploitation processes (Gray, 2006; Storey, 2016; Varis \& Littunen, 2010). Potentially, new employees play a key role in the maintenance of this innovation dynamic through their beliefs, behaviors, competences and initiatives (Hayton, 2003; Hayton, Hornsby \& Bloodgood, 2013; Heneman \& Tansky, 2002). However, socialization processes in ESFs are often under threat even if newcomers have been well-selected and previously tested (Cardon \& Stevens, 2004; Rollag, Parise \& Cross, 2005). Newcomers may face difficulties in understanding and complying with their new roles, which can lead to departures or conflictual relationships with insiders to the detriment of the innovation process (Ellis,

\author{
Emilie Bargues \\ ESC Clermont - CRCGM \\ emilie.bourlier-bargues@esc-clermont.fr \\ Bertrand Valiorgue \\ Université Clermont Auvergne - CRCGM \\ bertrand.valiorgue@uca.fr
}


Bauer, Mansfield, Erdogan, Truxillo \& Simon, 2015; Nelson, 1987; Nifadkar \& Bauer, 2016).

The socialization of newcomers is an issue that is generally analyzed through the theory of organizational socialization, which is defined as "the process by which an individual acquires the social knowledge and skills necessary to assume an organizational role" (Van Maanen \& Schein, 1979: 211). It constitutes a central process to maintain key institutions and, in particular, organizational roles (Solinger, van Olffen, Roe \& Hofmans, 2013; Van Maanen \& Schein, 1979). Organizational socialization scholars have not only identified and documented different forms of socialization activities implemented by insiders, but also those implemented by newcomers to facilitate newcomers' understanding and compliance with their new roles (Bauer, Bodner, Erdogan, Truxillo \& Tucker, 2007; Jones, 1986; Saks, Uggerslev \& Fassina, 2007; Van Maanen \& Schein, 1979). However, for a growing number of scholars, these socialization activities constitute "black boxes" as it is particularly challenging to understand how they emerge, interact and lead to the maintenance of organizational roles (Saks \& Gruman, 2012; Wanberg \& Choi, 2012). If we understand through quantitative research designs that some socialization activities lead to positive socialization outcomes and effective transmissions of expected roles, it is difficult to explain and describe what is actually achieved during socialization processes (Ashforth, 2012; Vancouver \& Warren, 2012). In this research, we propose to answer the call of organizational socialization scholars who propose to develop new research settings and empirical investigations to shed light on the mundane activities of socialization and their dynamics (Ashforth, Harrison \& Sluss, 2014; Klein, Polin \& Leigh Sutton, 2015; Solinger, et al., 2013).

To capture what insiders and newcomers actually do during socialization processes in ESFs, we propose to develop an institutional work perspective (Delacour \& Leca, 2011; Lawrence, Leca \& Zilber, 2013; Lawrence \& Suddaby, 2006; Lawrence, Suddaby \& Leca, 2009, 2011). Institutional scholars have recently studied organizational socialization and have shown that socialization is a key process to maintain expected organizational roles (Dacin, Munir \& Tracey, 2010; Heaphy, 2013; Zilber, 2002,2009 ). They show that insiders implement a series of socialization activities to maintain organizational roles (Zilber, 2002).

Drawing on a comparative qualitative methodology, we conducted a real-time longitudinal research (Eisenhardt \& Graebner, 2007) of the onboarding processes of two newcomers in two ESFs for two years. We identify various categories of socialization activities enforced by insiders and newcomers. We show how these activities interact and what they achieve through a dynamic model of socialization. We demonstrate that the dynamic of socialization in ESFs potentially leads to two complementary and contradictory forms of institutional work: role maintenance and role creation.

In developing our arguments, we contribute to the organizational socialization literature as we focus on the "black boxes" of socialization in shedding light on the content and entanglement of mundane socialization activities separately or jointly enforced by insiders and newcomers in the understudied context of ESFs (Bargues \& Perrot, 2016; Perrot, Bauer, Abonneau, Campoy, Erdogan \& Liden, 2014; Rollag \& Cardon, 2003; Rollag, et al., 2005). We also contribute to the institutionalist studies by showing that newcomers are not passive agents of socialization and play an active role in maintaining organizational roles. This complements recent research that shows how individuals influence institutions and, more 
particularly, the emergent interest in low-power actors and the forms of agency they draw on to maintain institutions (Battilana, Leca \& Boxenbaum, 2009; Canales, 2012; Heaphy, 2013; Smets \& Jarzabkowski, 2013). We also propose new insights on the dynamics of socialization processes and show that, in the context of ESFs, these processes not only lead to maintaining organizational roles but also to the broadening of role drifts and innovation dynamics.

We first review the literature on organizational socialization and show that it struggles to capture mundane socialization activities enforced by insiders and newcomers. We then develop an institutional work perspective to complement this literature by offering conceptual resources for capturing mundane socialization activities and their dynamics in the context of ESFs. Further, we present our methodological settings, and we finally present our results and delineate avenues for future research.

\section{SOCIALIZING NEWCOMERS IN ORGANIZATIONS: SEQUENCES, TACTICS AND INITIATIVES}

Organizational socialization is an important topic in management and organizational studies (Wanberg, 2012), and scholars have identified different sequences of socialization that lead newcomers to understand, learn and comply with various institutions inside their new organizations and, more specifically, their organizational roles (Ashforth, Sluss \& Saks, 2007; Feldman, 1976, 1981; Schein, 1978; Wanous, 1991). They also demonstrated that if newcomers do not succeed in complying with institutionalized norms, practices or behaviors, they experience conflicts and generally leave the organization (Bauer, Morrison, Callister, 1998; Wanous, 1980). Based on these previous conclusions, socialization scholars have progressively documented various socialization activities or tactics enforced by insiders to structure socialization processes and encourage newcomers to learn and comply with their expected roles (Klein \& Weaver, 2000; Van Maanen \& Schein, 1979; Wesson \& Gogus, 2005). They fragmented socialization processes into different sets of onboarding activities implemented by insiders and tested how these activities lead to positive or negative specific socialization outcomes (Ellis, Bauer \& Erdogan, 2014; Klein \& Heuser, 2008), such as job satisfaction, organizational commitment and innovative versus custodial role orientation (Allen \& Meyer, 1990; Bauer, et al., 2007; Saks, et al., 2007).

A complementary stream of research progressively emerged and focused on proactive socialization activities which are developed by newcomers. In this view, newcomers are not passive agents of socialization. They take initiatives to navigate the ambiguity and lack of knowledge regarding the behaviors, beliefs, interaction patterns and skills required by their new roles (Ashford \& Black, 1996; Saks, Gruman \& Cooper-Thomas, 2011). In their integrative review, Cooper-Thomas and her colleagues distinguish three categories of newcomers' socialization activities (Cooper-Thomas, Anderson \& Cash, 2011; Cooper-Thomas \& Wilson, 2011): changing expected organizational roles and work environments, changing themselves, and mutual change (themselves and organizational roles). Considering socialization activities enforced by insiders, socialization scholars developed empirical tests to observe if newcomers' socialization activities are positively or negatively associated with different socialization specific outcomes, such as task mastery, job satisfaction and job performance (Ashford \& Black, 1996; KammeyerMueller, Livingston \& Liao, 2011; Saks, et al., 2011). 
From the identification of socialization sequences to the study of the joint effect of specific socialization activities enforced by insiders and newcomers, organizational socialization studies have considerably increased our knowledge of socialization processes. However, the literature struggles to capture mundane socialization activities as scholars focus on the impacts of various sets of socialization activities on different socialization specific outcomes (Ashforth, 2012; Vancouver \& Warren, 2012). While we know that some of the socialization activities positively or negatively affect the behaviors, performance or attitudes of newcomers, and lead to more or less positive dynamics of socialization, it is challenging to understand what mundane socialization activities are and how they interact. Ashforth, et al. (2014) recently emphasized that socialization activities enforced by insiders and newcomers constitute "black boxes," as it is particularly difficult to capture their emergence, contents, transformation and mundane interactions.

\section{SOCIALIZATION PROCESSES, INSTITUTIONAL WORK AND THE MAINTENANCE OF ORGANIZATIONAL ROLES}

Several scholars associated with the institutional work perspective have recently identified socialization activities as key activities for maintaining institutions and, in particular, existing organizational roles when newcomers come on board (Dacin, et al., 2010; Heaphy, 2013; Zilber, 2002, 2009). In this vein, socialization processes are not those that organizations master but those that insiders and newcomers jointly construct, experience and adapt to contingencies in order to maintain organizational roles and their associated dimensions (behaviors, practices, rules, relation patterns and values) (Heaphy, 2013). They show that, similar to any institution, organizational roles are not self-reproducing (Taupin, 2012; Zucker, 1988), and that the maintenance of institutionalized roles requires work and efforts through dedicated socialization activities to avoid erosion and drift (Lawrence \& Suddaby, 2006).

Dacin, et al. (2010) investigated the socialization processes of young members of the British upper class. They show how formal dining rituals at the University of Cambridge contribute to the maintenance of roles of the British class system. Toward a grounded interpretive approach, they describe how specific rituals (for example, following a script during ceremonies or extensive monitoring through tradition and custodians) allow insiders to control the internalization of key values. They also demonstrate how these socialization activities accomplish a shift in social position toward the development of cultural knowledge and social networks. Another work is Zilber (2002), which shows how nurses in a rape crisis center socialize newcomers. Toward an ethnographic methodology, Zilber (2002) studied learning activities implemented by organizational members in order to onboard new nurses, and shows that insiders do not transmit role expectations homogenously but tend to make a selection between the compulsory aspects of the role and potentially negotiable expectations. Heaphy (2013) recently developed research dedicated to the repairing of role breaches when newcomers enter an organization and unconsciously change some key aspects of their roles. She reveals that insiders enforce repairing activities only when role breaches concern "an institutionalized belief about a role that is taken for granted" (Heaphy 2013: 21).

Institutional work offers valuable conceptual resources for capturing the various socialization activities enforced by actors to maintain organizational roles. This framework allows us to develop a practice-based approach of socialization processes with a focus on mundane activities as 
the basic unit of analysis (Nicolini, 2012; Østerlund \& Carlile, 2003; Smets \& Aristidou, 2017). It also provides us with a theoretical frame to explain the dynamics of mundane socialization activities, how they are generated, and how they interact over time (Feldman \& Orlikowski, 2011). It will help us to highlight, in the context of ESFs, how newcomers and insiders interact and mutually adapt their socialization activities to maintain organizational roles and potentially exploit role breaches to innovate.

\section{METHODOLOGY}

Our research design aims at observing socialization activities and their interactions during the onboarding process of newcomers in ESFs. Interviews, conversations and direct observations constitute productive empirical tools for achieving this goal as they offer opportunities to capture mundane socialization activities and the significant norms, representations and beliefs associated with them (Simpson, 2009). We conducted real-time longitudinal research (Eisenhardt \& Graebner, 2007) of the onboarding processes of two newcomers in two ESFs for two years. We adopted a qualitative comparative methodology and used a theoretical sampling strategy by controlling the similarities and differences between the cases for further theory development (Glaser \& Strauss, 1967; Heaphy, 2013). The two firms of our sample were undertaking recruitment and had the following typical characteristics of ESFs: small size, constant innovation, creativity, risk taking and balance between exploration and exploitation processes (Heneman, Tansky \& Camp, 2000). We compared the socialization processes of two newcomers with similar skills and levels of work experience. Each was a technician, held a bachelor's degree, and had limited experience of the job. Neither was a relative of the entrepreneur.

\section{EMPIRICAL DATA COLLECTION}

Our data covered a period that started just before the entry of the two newcomers and was completed two years later. Our empirical materials come from interviews, observations, informal discussions, documents consultation and feedback sessions with the two entrepreneurs.

Interviews. We undertook 30 semi-structured interviews (60 to 90 minutes) with the top managers, newcomers and insiders. We conducted interviews at four points in time: during the anticipatory period of socialization (before the new recruit's arrival), during the encounter period of socialization (less than one month after arrival), during the adaptation period (between three months and one year after arrival), and finally two years after the newcomer's entry (Ashforth, 2012; Wanous, 1991).

Observation. Interviews were supplemented by eight instances of observation. We observed newcomers in different areas and at different stages of the onboarding process. We shadowed the newcomer in each ESF during their first day of work. We shadowed them a second time one month after their arrival, and then two months and four months later, for a total of 38 hours. This observation enabled us to witness meetings, daily discussions and other socialization situations.

Documents. Our contacts provided us with internal documents and communication materials. We had access to promotional brochures, business cards, email exchanges, intranets, websites, induction manuals and various working documents. These documents helped us to 
understand the organizational context and the roles assigned to the two newcomers (functional, hierarchical and social aspects).

Feedback sessions with entrepreneurs and informal discussions. At the end of the data collection period, we conducted one feedback session with each entrepreneur, and we reported and discussed our findings. In addition, we had informal discussions during the interviews of periods 2, 3 , and 4 with the newcomers and their colleagues. We took advantage of these two types of exchanges to complement and compare the primary analyses of the data. Table 1 summarizes the organization of our data collection.

\begin{tabular}{|l|l|l|l|l|}
\hline & $\begin{array}{c}\text { Anticipatory } \\
\text { phase (before } \\
\text { arrival) }\end{array}$ & $\begin{array}{c}\text { Encounter } \\
\text { phase (<1 } \\
\text { month after } \\
\text { arrival) }\end{array}$ & $\begin{array}{c}\text { Adaptation } \\
\text { phase (3-12 } \\
\text { months after } \\
\text { arrival) }\end{array}$ & 2 years later \\
\hline Entrepreneur & 2 interviews & 2 interviews & 2 interviews & 2 interviews \\
\hline Newcomer & & 2 interviews & 2 interviews & 2 interviews \\
\hline Colleague 1 & & 2 interviews & 2 interviews & 2 interviews \\
\hline Colleague 2 & & 2 interviews & 2 interviews & 2 interviews \\
\hline Colleague 3 & & 2 observations & 6 observations & 2 interviews \\
\hline Observation & & & & 2 sessions \\
\hline Feedback & & & & \\
\hline
\end{tabular}

Table 1 - Organization of observations, interviews and feedback sessions in the two ESFs

\section{DATA ANALYSIS}

The data collected through interviews, document analysis, informal discussions and direct observations were analyzed through a qualitative and inductive approach (Corbin \& Strauss, 2007; Gioia, Corley \& Hamilton, 2012). We cycled among data and relevant literature to develop a deeper understanding of socialization activities and their dynamics in the context of ESFs (Langley, 1999; Rouleau \& Balogun, 2011).

We started with the identification and observation of socialization activities that helped the newcomers to understand the different expectations associated with their roles (behaviors, practices, norms and patterns of interactions). We also identified who was concerned by these socialization activities and we observed how they reacted and interacted together. We undertook a first-order analysis of these socialization activities involving a thorough coding of the interviews, company documentation, informal and formal discussions and observation transcripts (Clark, Gioia, Ketchen \& Thomas, 2010). Examples of the first codes that we used include "pointing out errors or faux pas," "using different methods" and "allocating resources for a test".

We continued the first-order analysis, which provided a voice to the individuals interviewed (Gioia, et al., 2012), during the second phase of coding (Strauss \& Corbin, 1998) to identify relationships between and among these first-order codes and to gather them into higher-order 
themes. We connected these themes with the literature on organizational socialization and institutional work. Examples of second-order themes that emerged from this process included "verbal guidance," "information seeking" and "policing".

This second-order analysis was succeeded by a third and final phase, which resulted in the identification of five aggregate dimensions (Gioia, et al., 2012). These dimensions represent key socialization activities enforced by newcomers and insiders. The overall structure of the coding is synthetized in Figure 1. Appendix 1 presents the representative data associated with the first-order, second-order and aggregate concepts. In Appendix 2, we present the occurrence of the first-order themes in our interviews and observations.

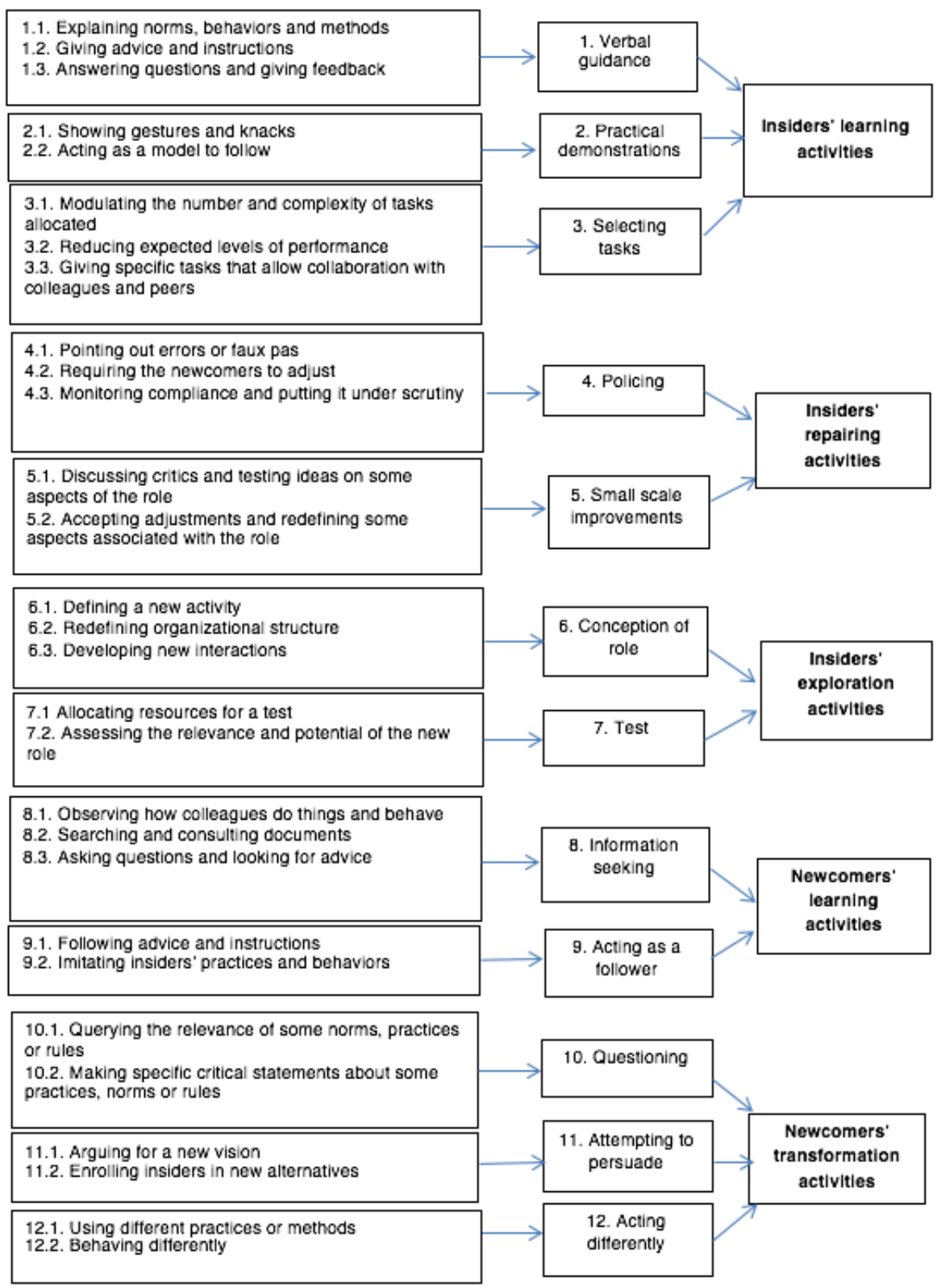

Figure 1 - Data structure 


\section{RESULTS}

In the following section, we document mundane socialization activities enforced by newcomers and insiders during socialization processes in ESFs. We show how these activities interact and lead to two forms of work: the maintenance of institutionalized roles and the creation of new ones. We integrate our results in a dynamic model of socialization in ESFs (see Figure 2). Before presenting the content of socialization activities and their dynamics, we introduce the context of this research.

\section{RESEARCH CONTEXT}

\section{THE ONBOARDING CONTEXT OF LUCA AT SUTTON LIMITED}

Sutton is a forestry management and logging firm with ten employees. It was established three years prior to our investigation. The founder wanted to create a new hybrid profession in the French wood industry, combining the skills of a forest technician and forest manager. Sutton's clients are forest and private-park owners, local communities and municipalities. Sutton underwent a rapid expansion in terms of turnover and has introduced innovative technologies in forest businesses, particularly in safety equipment. The organization of work at Sutton is characterized by a flat structure, decentralization of decisions, polyvalence and autonomy. At Sutton, we observed the socialization of Luca, a 24-yearold man who has a bachelor's degree in environmental management with previous experience of logging. $\mathrm{He}$ is a strong advocate of environmental protection. Luca was hired as a forest technician and joined a team of two technicians. A forest technician has a good knowledge of forestry exploitation and trade activities. He directly interacts with forest owners. He has absolute autonomy and manages a small team of forest workers. This job is associated with institutionalized practices and methods developed and taken for granted within the profession.

\section{THE ONBOARDING CONTEXT OF JOHN AT COVAX}

Covax is a geotechnical consultancy and design firm employing 19 people. The firm was established eight years prior to our study. It offers consultancy and design services and products that are unique and original. Its main customers are local councils, construction firms and engineering and audit offices. With $10 \%$ of its annual turnover allocated to research and development activities, innovation is a central activity which has resulted in several patents. Covax has progressively diversified its competences and its service provision, in particular the range of processes and materials it develops for its customers. Covax has three main activities: conception, development and commercialization of geotechnical equipment and geotechnical engineering services. The new recruit we observed, called John, is a 26-year-old man. John holds a bachelor's degree in geophysics and had brief experience in another engineering office. At Covax, John was hired as a geotechnical technician specializing in geophysical fields. The job of a geotechnical technician, which is already undertaken by five employees, refers to the development and construction of geotechnical tools adapted to the specific needs of customers. This implies that a geotechnical technician should have good knowledge of mechanics and possess expertise in geophysics. This job is associated with institutionalized methods, practices and interaction patterns, such as project methodology and shared use of prototyping software. 
Maintenance and creation of roles during socialization

processes in entrepreneurial small firms

M@n@gement, vol. 22(1):30-55

In the table below, we summarize the characteristics of our research context.

\begin{tabular}{|l|c|c|c|c|c|}
\hline & $\begin{array}{l}\text { Firm size } \\
\text { and age }\end{array}$ & Firm activity & Key values & $\begin{array}{c}\text { Role given } \\
\text { to the } \\
\text { newcomer }\end{array}$ & Newcomer \\
\hline Sutton & $\begin{array}{c}10 \text { members } \\
3 \text { years old }\end{array}$ & $\begin{array}{c}\text { Forestry } \\
\text { management } \\
\text { and logging }\end{array}$ & $\begin{array}{c}\text { Innovation, } \\
\text { security, } \\
\text { nature, trust }\end{array}$ & $\begin{array}{c}\text { Forest } \\
\text { technician }\end{array}$ & $\begin{array}{c}24 \text { years old, } \\
\text { bachelor's degree, } \\
\text { limited experience }\end{array}$ \\
\hline Covax & $\begin{array}{c}\text { 19 members } \\
8 \text { years old }\end{array}$ & $\begin{array}{c}\text { Geotechnical } \\
\text { consultancy } \\
\text { and design }\end{array}$ & $\begin{array}{c}\text { Innovation, } \\
\text { cooperation } \\
\text { respect of } \\
\text { professional } \\
\text { norms }\end{array}$ & $\begin{array}{c}\text { Geotechnical } \\
\text { technician }\end{array}$ & $\begin{array}{c}26 \text { years old, } \\
\text { bachelor's degree, } \\
\text { limited experience }\end{array}$ \\
\hline
\end{tabular}

Table 2 - Characteristics of research contexts

\section{SOCIALIZATION ACTIVITIES AND THE MAINTENANCE OF ORGANIZATIONAL ROLE}

When John and Luca joined their respective ESFs, insiders enforced a set of learning activities to help them to understand and comply with the technical, hierarchical and social aspects of their roles. At Sutton and Covax, learning activities refer to actions undertaken by insiders to help newcomers to learn and make sense of their new roles. They take three complementary forms: verbal guidance, practical demonstration and adaptation of tasks.

In the two cases, insiders start the newcomers' learning activities by providing them with verbal guidance on the tasks, methods, interaction patterns and behaviors that they have to follow. Insiders explain the rationale for these work practices and behaviors by developing conversations and telling stories about their origins and meanings. These discursive learning activities helped the two newcomers to discover and make sense of the cultural foundations associated with their new organizational roles.

As role models, insiders showcase the right on-the-job behaviors and gestures to complement and illustrate discursive activities. This second learning activity is based on practical demonstrations of the right gestures, techniques and behaviors that newcomers have to master. They show how to touch and manipulate tools, use machines or identify the smell of a malfunctioning device.

When you smell this odor, it is not good. Do you smell it? The insider turns off the machine and goes to find water. If you smell this odor, turn off the machine immediately. Let it cool down 2 minutes and then add water, just right here. [Observation stage 1 - Sutton]

Insiders' demonstration activities are also linked to the behavioral attitudes of not only the concerned colleagues, but also external stakeholders. Insiders show how to act and behave in front of these partners and sometimes tend to overplay the role. 
We met a customer who is now a friend of mine, but as John was here, I decided to adopt a very formal tone during our conversations. He had to see how professional we are with our customers. [Insider at Covax - Interview serie 2]

Complementary to verbal guidance and practical demonstrations, insiders at Sutton and Covax implemented another form of learning activity that consists of selecting and simplifying the tasks that newcomers must accomplish to facilitate their learning. Insiders select tasks and projects that contribute directly to the work flow of the organization but simplify these tasks and provide time for the newcomers to execute them. They have tasks and work on projects that are not secondary or peripheral activities. These tasks are accomplished in direct collaboration with insiders as they require specific competences and complex interactions with the other members of the organization. As a result of the assignment of these important tasks, newcomers are not isolated but are strategically positioned in order to constantly interact with colleagues and maximize their learning.

From their perspectives, Luca and John do not passively face insiders' learning activities. They take two forms of initiatives to facilitate their learning: they search for information and act as conscientious followers. Newcomers look for information regarding gestures, practices, behaviors and mode of social interactions. They also carefully observe, listen to and ask many questions to insiders.

Luca went with me to meet a client. I understood that he observed and listened because when we went back to the office, he asked me a lot of questions: "Why did you say that? Why did you do that?". [Entrepreneur at Sutton - interview 2]

Luca and John also put significant amounts of effort into carefully imitating insiders and complying with what was expected. They carefully followed advice and imitated behaviors and gestures, showing these efforts to the insiders.

Learning activities enforced by newcomers interact with learning activities developed by insiders. Insiders face many questions, which allow them to understand the difficulties that newcomers encounter while understanding the different aspects of their roles. Insiders directly help newcomers to refine their verbal guidance and provide more accurate and precise explanations, in addition to pushing the newcomers to adapt to tasks and role assignments regarding specific difficulties encountered by insiders. Insiders also adapt their practical demonstrations to aspects that are not well understood by newcomers. Through these complementary sets of learning activities, insiders and newcomers jointly and actively participate in the maintenance of the technical, hierarchical and social aspects of organizational roles.

If Luca and John do not understand immediately what is expected and what needs to be done, they also feel uncomfortable with some aspects of their roles. In the two cases observed, the newcomers questioned the relevance of some norms, technologies, work methods, social interactions and procedures. They proposed some changes or directly acted and did things differently in accordance with what appeared relevant to them. These transformation activities of newcomers disturbed the existing expectations of roles and introduced role breaches. These breaches pushed the insiders to implement repairing activities that took two complementary forms-adjustments or policing activities-depending 
on the impacts of the breaches on newcomers' roles. Some aspects of the role appear negotiable and others compulsory. Breaches are judged positively and are exploited if they improve the role without changing its nature through small-scale adjustments. In this case, insiders take into consideration these breaches and open negotiation with newcomers; they listen to the newcomer's criticisms and propositions and ask for practical alternatives and tests. If these criticism and propositions are in line with the representations of the role and lead to improvements, the insiders tend to accept and make the adjustments.

I had the opportunity to modify this procedure I considered to be complicated. [...] I was invited to a management meeting, where I defended my idea. I found good arguments to back-up my criticism and worked on my solution. [Newcomer at Covax - interview serie 4]

However, when insiders consider that these breaches affect important aspects of the role, they implement policing activities that consist of explaining the disconnection between the initiatives taken by newcomers and the rationales and cultural foundations of the role. Insiders explain to the newcomers what they expect and why it is important to respect this. Unlike learning activities, policing activities encompass formal and authoritarian tonalities. At Sutton, the newcomer deviated from an important clothing norm associated with his role of a forest technician. The entrepreneur explained what he meant by the dress code and why it was important for the image he wanted to present to the customers. Finally, he told him that he expected a prompt adjustment.

He's young and he's dressed very fashionably, whereas our client expects someone to be a bit like a "forestry expert"; white shirt, green sweater, even a jacket. [...] I told him that he has to understand that appearances are important in our job and that he must comply. [Insider at Sutton, interview serie 3]

Monitoring and scrutinizing activities are also implemented collectively by insiders who are informed of the disruption. This refers to observing and controlling the compliance of newcomers with the requirements of the roles that they are challenging. Insiders observe newcomers carefully through the construction of a normative network of actors, through which newcomers' transformations become normatively sanctioned with respect to the existing aspects and those that are considered as key aspects of the roles. This set of policing activities pushes newcomers to stop transformation activities and strictly follow norms and practices that they deliberately or inadvertently challenged.

\section{SOCIALIZATION ACTIVITIES AND THE CREATION OF A NEW ORGANIZATIONAL ROLE}

The socialization of Luca at Sutton allows us to consider a different and complementary dynamic of the socialization process in ESFs. Luca was deeply unsatisfied with the negative environmental consequences of his forest technician role and, after six months, he understood that insiders did not want to change and reconsider this role which was central for the business activity of Sutton. 
Our practices have huge bad effects on the environment and we destroy many nests and plants, such as orchids[...] They told me that I have to get used of that. For them, I am romantic and my propositions are economically out of step. I don't know if I will stay here. [Interview insider - serie 3, Sutton]

After having considered leaving Sutton, Luca decided to comply with his role and its negative environmental consequences, but he continued to discuss environmental issues with the insiders. Luca is convinced that his job could be done differently, and he started demonstrate to the insiders that green issues have to be taken into consideration for the future of the business. He provided practical illustrations of how to do things differently, as he wanted to push his colleagues to act and think differently. His transformation activities took three forms: querying the relevance of Sutton's practices, arguing for alternatives and enrolling insiders to his vision.

Luca initiated discussions around ecological issues associated with the business practices of Sutton. He showed the insiders how the practices badly affected the environment and some animals. He pushed them to more carefully observe the presence of specific plants and animals that were put in danger by their practices.

He showed us a nest that I have never seen before and he taught us a few details about a mammal living in the bushes. [...] I think it's true that we could be more careful about them on the work-sites [...] We had exchange about this important environmental issue and this is good. [Interview insider - serie 3, Sutton]

Luca also demonstrated to the insiders how green issues and animals could be taken into consideration, and he provided practical illustrations of how to do things differently.

If we use organic oil, this would reduce our negative impacts. I explained several times that orchids are significantly sensitive to mineral oil and that we could switch easily to organic oil. I showed them how to change and now we use organic oil. I was very happy about this evolution. [Interview newcomer - serie 4, Sutton]

These talks and discussions with insiders convinced Luca that the insiders can evolve and change their practices. After one year of talks and his experiences with the insiders, Luca decided to directly talk to his boss about his vision, as he wanted to convince him that Sutton could be more active in the defense of animals and plants without deteriorating its business.

What struck me was his expression that we no longer can exploit forests as we used to do it in the XXth century. Putting ecology in our business, I find it extra. He has strong convictions and I think that we can no longer work in the forestry business nowadays without a sustainable vision. He is right to push us in this direction. [Feedback manager, Sutton]

Luca's transformation initiatives led insiders and Sutton's manager to think and develop new ideas related to the mission of the firm. Sutton's manager was convinced that he had to change and adapt the business practices to integrate environmental issues. He asked Luca and his 
colleagues to explore with him new possibilities regarding Sutton's mission, competences and business activities. Luca and the insiders started to implement exploration activities that took two forms: conception and testing of a new organizational role inside Sutton.

After several weeks of discussions between Luca and his colleagues, the outlines of a new organizational role were formed: the role of a forest animator, which consisted of developing and commercializing an activity to discover and sensitize citizens to the ecological issues in forests. Luca and his colleagues identified the competences in terms of marketing and environmental knowledge as well as the new managerial tools (leaflets, compasses, books and digital tablets) required for the new role. They also investigated how the organizational structure of Sutton should evolve to develop better internal and external interactions with customers.

They defined a new target of customers and proposed tourist structures. Good idea! I had a rather good knowledge of them. I helped Luca to get in touch with them to test his idea [...]. We also decided to directly link his animation forest activity to me. He convinced us that it was strategic. [Interview manager - serie 4, Sutton]

Insiders' exploration activities continued and moved to a testing phase after an important meeting with Luca when he presented his project to the manager and insiders. Following this meeting, Sutton's manager decided to allocate resources and provide time to Luca for starting a new role.

Since the arrival of Luca one year and a half ago, we talked a lot about environmental issues. His idea of forest animation was interesting, but we needed evidences of its relevance for Sutton. Luca made a market survey and crafted a sort of business plan. After his presentation, we decided to go for it. We gave him time and resources to develop and give consistency to his idea. [Interview insider - serie 4, Sutton]

Since the meeting, Luca performs two roles. He continues to work as a forest technician and has started his project of forest animation. Insiders give advice and participate in different activities to improve his role. Through this complementary set of exploration activities, the insiders and newcomers jointly and actively participate in the creation of the role of forest animator and the reconfiguration of Sutton's mission. The insiders and Luca jointly changed the organizational structure and developed new competences and behavioral norms. They also constructed new internal and external interaction patterns with new stakeholders and introduced a new cultural value in the organization-ecology-associated with Luca's new organizational role.

I know that the first year was difficult for him. He told me that he wanted to leave Sutton. He is very determined. He forced us to ask new questions and transform our activity. It is very positive for Sutton. Forest animation could be a huge success. [Feedback with the manager - serie 4, Sutton] 


\section{SOCIALIZATION AS AN AMBIDEXTROUS PROCESS}

When newcomers start new positions, it is not easy and obvious for them to act in ways that are consistent with the behaviors, beliefs and relational norms associated with their organizational roles. The maintenance of an organizational role necessitates efforts and complementary activities enforced separately and sometimes jointly by newcomers and insiders. Learning activities open the socialization process and allow newcomers to acquire the necessary technical, social and hierarchical dimensions associated with their roles. Newcomers play a central role in this learning dynamic, but learning is necessarily incomplete and newcomers deliberately or inadvertently take initiatives that transform some aspects of their roles and introduce breaches. When insiders consider that these breaches improve the role without changing its foundations, they can lead to tests and trials for role negotiation and improvements. However, if these breaches are perceived as disruptive, insiders enforce policing activities to encourage newcomers to comply with what is expected. The maintenance of organizational roles in ESFs appears as a complex process with a mix of learning, improvements and compliance pressures that can destabilize newcomers.

The socialization of Luca at Sutton shows that insiders can accept newcomers' transformation initiatives as sources of positive change and start an exploration dynamic. Interactions and entanglement between newcomers' and insiders' transformation activities lead to the creation of a new organizational role. Newcomers are agents of change and push insiders to explore new possibilities. Socialization processes may lead to important innovations and reconfigurations. Socialization processes in ESFs appear as ambidextrous processes during which insiders and newcomers not only exploit newcomers' transformation activities for existing roles but also for exploring and creating new ones.

In the following graph, we summarize the two fundamental dynamics at play during socialization processes in ESFs and the various socialization activities enforced by newcomers and insiders.

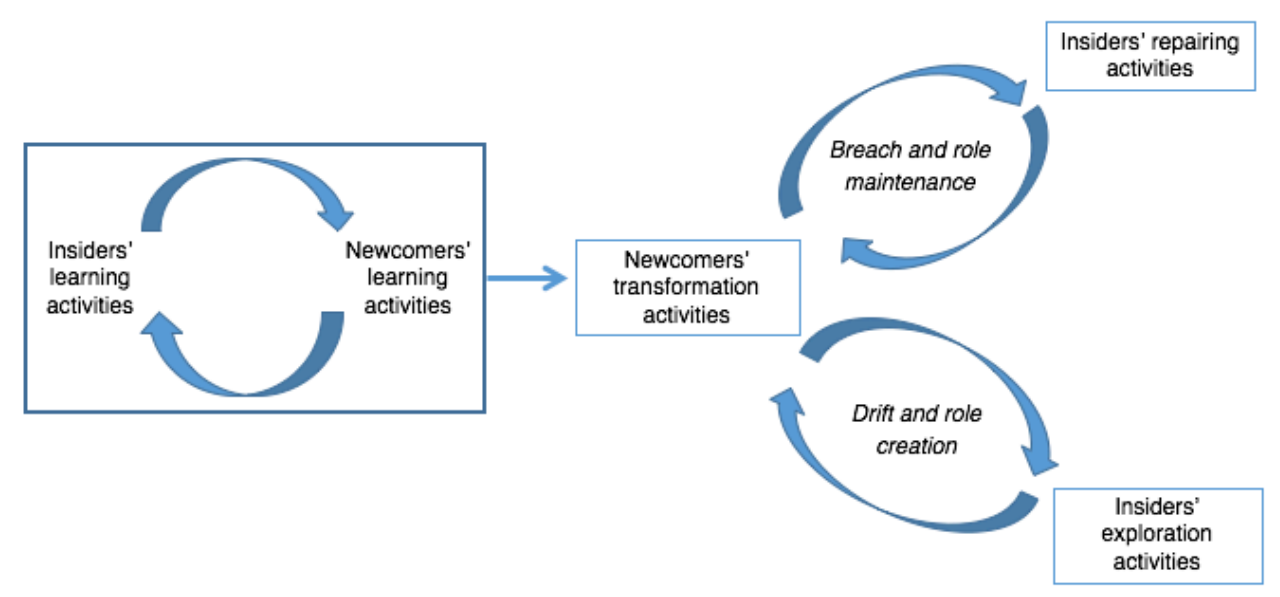

Figure 2 - Activities of socialization and their dynamics in ESFs 


\section{DISCUSSION}

In this research, we observe mundane socialization activities enforced by newcomers and insiders in ESFs from an institutional work perspective. We show that two dynamics are at play: the maintenance and creation of organizational roles. Our findings allow us to contribute both to organizational socialization theory and to the institutional work literature, as we explain below.

\section{CONTRIBUTION TO ORGANIZATIONAL SOCIALIZATION THEORY}

Content and dynamics of mundane socialization activities. A growing number of socialization scholars have recently highlighted a lack of knowledge about what is actually achieved during socialization processes (Ashford \& Nurmohamed, 2012; Bauer, Erdogan \& Taylor, 2012; Solinger, et al., 2013). They call for new investigations to shed light on "the nuanced dynamics of onboarding processes" (Ashforth, et al., 2014: 12). In our research, we identified different categories of socialization activities. We have also shown that change in socialization activities occurs as reactions to various outcomes of previous iterations of these activities. Our study considers insiders' and newcomers' socialization activities not as static entities but as co-evolving activities through enduring interactions.

Socialization in ESFs. With a few exceptions, socialization processes in small firms in general and ESFs in particular have not been studied (Bargues \& Perrot, 2016; Perrot, et al., 2014; Rollag \& Cardon, 2003; Rollag, et al., 2005). We designed specific research settings to document this blind spot. This focus on socialization processes in the context of ESFs allows us to answer the call for more contextually sensitive research and qualitative methodological settings (Ashford \& Nurmohamed, 2012). Our study of mundane socialization activities helps identify four categories of socialization activities in the specific organizational context of ESFs: learning, repairing and exploring activities enforced by insiders, and learning and transformation activities enforced by newcomers. We propose a dynamic model that shows how these activities interact and lead to the socialization of newcomers. We also show that the dynamic of socialization activities in ESFs have two types of outcomes: maintenance of a given role and creation of a new one. The dynamic between newcomers' transformation activities and insiders' exploration activities, which is at the heart of the role creation dynamic, is directly related to the context of ESFs, and this dynamic may be less frequent in other cultural environments where innovation is less institutionalized. The comparison between the two cases also shows that the creation of an organizational role is not the automatic result of the socialization process. This outcome depends on the capacity of newcomers and insiders to understand and enact contextual aspects related to the organization and the possibility of adapting their activity through role innovation.

Role creation as a distal outcome of socialization. Scholars have identified "proximal" socialization outcomes that indicate how well a newcomer is adjusting to his or her new role (Bauer, et al., 2007; Saks, et al., 2007). They have also identified "distal" outcomes that indicate the ultimate consequences and effects of organizational socialization (Bauer \& Erdogan, 2012), such as organizational commitment and job performance (Bauer, et al., 2007; Jones, 1986; Saks, et al., 2007). Our study contributes to the identification of potentially new distal outcomes of socialization processes (Erdogan, Bauer, Truxillo \& Mansfield, 2012) by showing that the creation of a new organizational role can be associated with the 
socialization process (Allen \& Meyer, 1990). This "distal" socialization outcome is observable in Levine's work (Hansen \& Levine, 2009; Levine, Moreland \& Hausmann, 2005), but to our knowledge, it has never been documented and empirically described.

\section{CONTRIBUTIONS TO INSTITUTIONAL WORK}

Institutional role maintenance and the contribution of newcomers. The process of role maintenance has been recently observed in the institutional work literature, and a central assumption of these pieces of research is that insiders mainly undertake it. They implement several socialization activities to help newcomers to acquire the social knowledge and skills necessary to assume their new roles (Dacin, et al., 2010; Heaphy, 2013; Zilber, 2002, 2009). In this study, we extend this emerging literature by showing that newcomers are also important actors. Through their initiatives, they directly participate in the maintenance of organizational roles. Although socialization scholars have documented the contributions of newcomers during socialization processes (Saks, et al., 2011), their contributions have been marginal to much institutional research, and institutional theorists have not engaged meaningfully with socialization activities enforced by newcomers to maintain roles (Heaphy, 2013; Zilber, 2009).

Our analysis highlights a number of activities enforced by newcomers that lead to the maintenance of organizational roles. Newcomers look for information, they observe, ask questions, look for advice and search documents in order to better understand their new roles. These activities allow them to develop an appreciation of the different dimensions of their new roles (technical aspects and interactions patterns). They also acquire specific knowledge regarding the values and norms associated with their roles. Moreover, newcomers act as followers and imitate insiders. Through these activities, newcomers experience their roles and, in practice, discover what they have to do and how to do it.

These results resonate with some recent institutional research that indicates that the maintenance of institutions, and in our case of an organizational role, is not limited to activities that are undertaken by privileged actors with high status and access to valuable resources (Battilana, 2011; Currie \& Spyridonidis, 2016; Heaphy, 2013). Low-power actors can be fully engaged in institutional work and can actively participate in the maintenance of institutions. When newcomers ask for information or question the relevance of a norm, they contribute to the enactment and reproduction of some key dimensions of organizational roles. When they experience and test some aspects, they also contribute to enforcing a role and reaffirming its essential characteristics. Organizational roles are situated, interpreted and reinforced by newcomers during the socialization process. We also shed light on the bargaining activities between newcomers and insiders. When newcomers contest some aspects of their roles and open breaches, this can lead to smallscale role adjustments. The maintenance of an organizational role is not a simple replication process, but a process composed of various activities that lead to transmitting compulsory dimensions and also to adjusting others. In summary, we show that the maintenance of an organizational role is not a mechanistic and automatic process, and actors with lower status actively participate in the maintenance process (Heaphy, 2013).

Creation of roles and dimensions of agency. This study also contributes to the discussion on agency issues by demonstrating how different dimensions of an agency interact dynamically in the maintenance 
and creation of organizational roles. One of the major theoretical issues that institutional work faces is related to the embedded agency debate, addressing the question of how actors become motivated and enabled to change the given practices and norms that supposedly define them (Seo \& Creed, 2002; Smets \& Jarzabkowski, 2013). Institutionalists have documented three main dimensions of an agency: iterative, projective and practical-evaluative. The iterative dimension underpins the reproduction of established practices and institutions. The projective dimension supports planning for the future and the creation of institutions. The practicalevaluative dimension enables actors to exercise judgment and implement existing practices in line with what they consider relevant (Emirbayer \& Mische, 1998; Smets \& Jarzabkowski, 2013). These three dimensions "like notes in a chord," jointly create the "tone" of agency, ranging from reproductive to transformative (Seo \& Creed, 2002: 222; Smets \& Jarzabkowski, 2013).

In this study, we contribute to this debate in two ways. We show that the maintenance of an organizational role is accomplished through an iterative form of agency as newcomers and insiders independently and jointly implement various socialization activities that contribute to the reproduction and maintenance of a role. Institutionalists tend to conceive this dimension of agency as unconscious and automatic, but our work suggests that actors involved in the reproduction of an organizational role are conscious of the importance of this institution and carefully implement sets of socialization activities to describe, test, experience and transmit the role to newcomers. From their perspective, newcomers perceive the importance of the institution and develop efforts to internalize the key aspects of the role and maintain it. Our empirical work encourages us to consider the iterative agency not as a mechanistic and unconscious process, but as a deliberate and effortful process accomplished by different actors (Heaphy, 2013; Zilber, 2002, 2009).

Moreover, the creation of a new organizational role, which we observed in Luca's case at Sutton, pushes us to reconsider some aspects of the practical-evaluative dimension of agency (Smets \& Jarzabkowski, 2013). This dimension of agency is generally attributed to institutional entrepreneurs (Battilana, et al., 2009) who have the capacity to implement a collective action to change institutions inside organizations as well as at the level of organization fields (Battilana, 2011; Battilana, et al., 2009; DiMaggio, 1988). These institutional entrepreneurs are conceived as powerful actors with high positions and access to valuable resources. Our study shows that institutional change can arise through mundane activities and localized initiatives of actors without important resources. Luca's case shows that this newcomer, who felt uncomfortable with some aspects of his job, was able to show insiders that things needed to change regarding environmental aspects. With the support of the insiders, he created a new business activity for his firm, introduced a new value in the culture and changed the organizational structure. The creation of this new organizational role was not planned by the entrepreneur or powerful insiders but was the result of a series of mundane activities, tests and discussions.

This finding sheds light on the nature of intentionality and effort in institutional work. In their daily activities, actors are not necessarily intentional in the sense of purposefully maintaining, disrupting or creating institutions; they accomplish practical activities and take initiatives that result in an evolution of the institutional order. Institutional entrepreneurs (Battilana, et al., 2009) are not always heroes with a great vision of the future, but actors embedded in work situations and mundane operations 
who introduce small variations and progressively craft institutions through a series of practical initiatives and tests.

\section{CONCLUSION AND AVENUES FOR FUTURE RESEARCH}

Socialization processes are important for many organizations, particularly for ESFs. As this research shows, socialization processes are jointly enforced by newcomers and insiders through mundane socialization activities. By engaging an institutional work perspective, it becomes possible to identify how these activities interact and lead to the maintenance and creation of organizational roles. This theoretical perspective offers a practical and contextual vision of socialization processes and introduces a new field of enquiry. It also reveals the skills and dimensions of an agency that is necessary for insiders and newcomers to engage in two forms of institutional work. Our study poses intriguing questions that we want to address in future work.

We have identified a set of socialization activities in the context of ESFs, but it appears important to develop new empirical investigations in this regard. We need to document the contents and interactions of complementary forms of socialization activities jointly or separately enforced by newcomers and insiders. In addition, future research should explore how two different dynamics of socialization emerge in the very same organization. At Covax, John made several propositions to change his role and do things differently, but these propositions only led to smallscale adjustments and minor role innovation. However, at Sutton, Luca managed to convince the insiders that a new role, a new structure and new external relationships could be useful for the firm. We need to further research these two different dynamics of socialization to understand why, in one case, there is a role creation dynamic but only role maintenance in the second.

Observing the content of the conversations and enactment forms that lead to comparing institutions and to the creation of a new organizational role appears of significant importance. In future research, we propose to decipher the enabling conditions of role creation in ESFs at the field, organizational and individual levels. We want to understand whether the dynamic of role creation is associated with societal transformations at the field level or is related to a receptive organizational context. The competence of the newcomer and their agentic capabilities may also be a source of explanation. Socialization processes in ESFs appear fundamentally linked to institutions; the various socialization activities enforced by insiders and newcomers allow organizational roles to be maintained, created and potentially disrupted. These investigations will have direct impacts on the current agency debates about the capacity of normal actors to implement a series of activities that progressively lead to comparing institutions and sustaining innovation dynamics (Smets \& Aristidou, 2017). 


\section{APPENDICES}

Appendix 1. Representative data of the fist-order and second-order themes, and aggregate categories

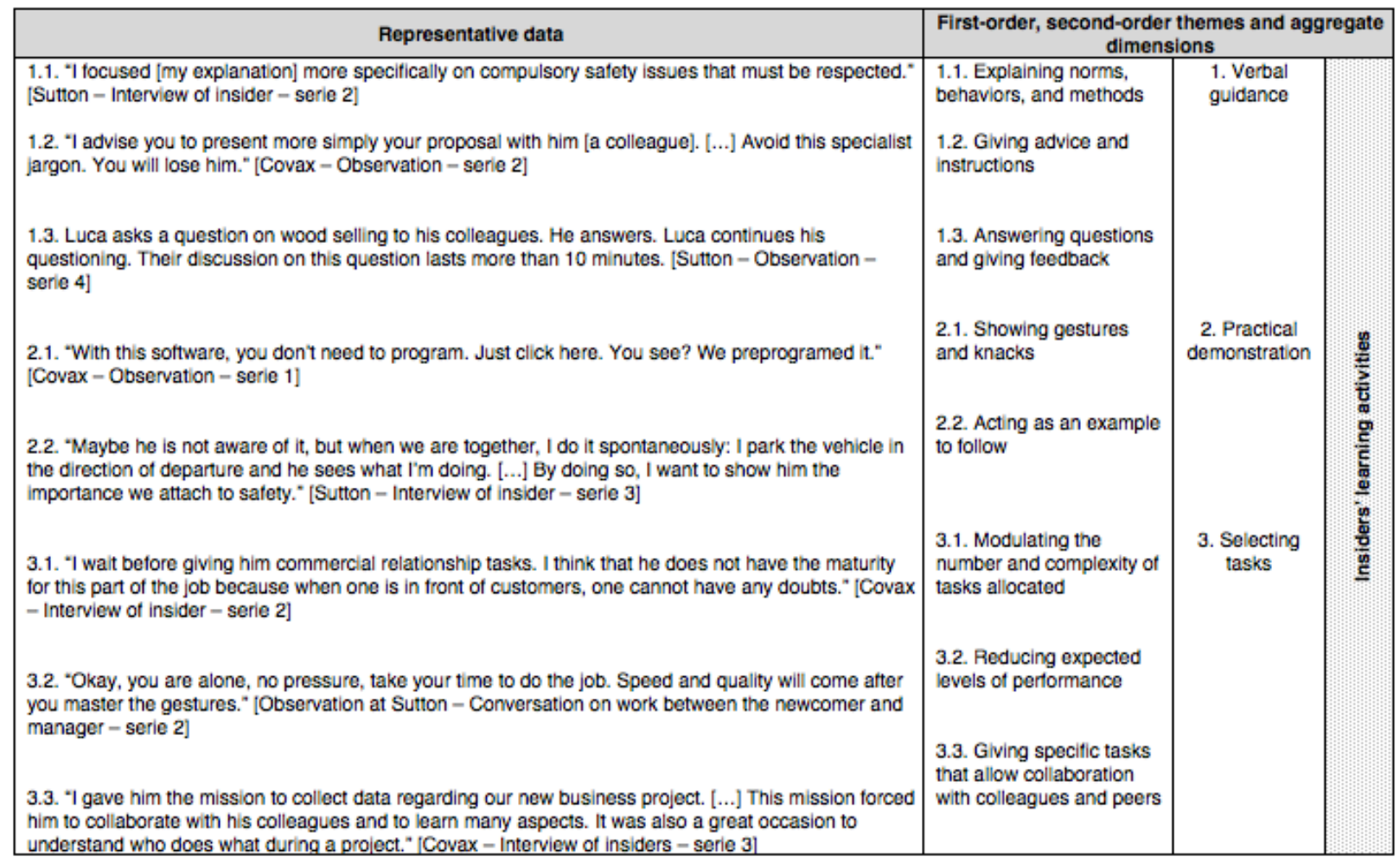

\begin{abstract}
4.1. "He was very rude. When the customer left our office, he came to me and told me: 'you are out of steps with our customers. You cannot behave in such a manner.' [...]'You're a schoolboy!.". [Covax Interview of newcomer - serie 3]
\end{abstract}

4.2. "He took the chain saw without his safety equipment. I was very upset as I told him that it was a compulsory rule.[...] I asked him to stop working, to go back to our office, and to wear his security trouser.." [Sutton - Interview of insider - serie 3]

4.3. "I have to monitor his behavior with our customers and I asked his colleagues to intorm me of any deviations. I want to be sure that he has clearly understood what I asked him to do and that he respects my requests." [Covax - Interview of insider - serie 3]

5.1. "He told me: "What's this procedure? It's too complicated!" I agreed. [...] He explained to me that he had an idea to simplify it. [...] I told him it was really clever." [Covax - Interview of insider - serie 4]

5.2. "When we came back to the office, he proposed to implement a new working document. [...] I said that it was a very good idea [...] We will work together on it." [Sutton - Interview of insider - serie 3]
4.1. Pointing out errors or faux pas

4.2. Requiring the newcomer to adjust

4.3. Monitoring compliance and putting under scrutiny

5.1. Discussing critics and testing ideas on some aspects of the role

5.2. Accepting

adjustments and redefining some aspects associated with the role

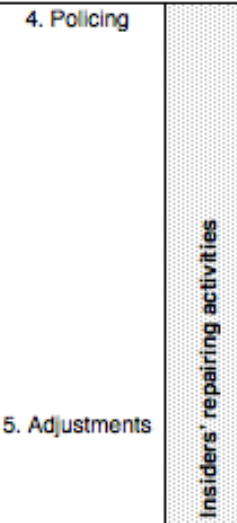


6.1 There was much discussions about the gap between a forest animation business and Sutton's corporate mission. [...] I gave my point of view. I said that raising awareness about the maintenance of the forest is already a part of our work with the forest owners. With forest animation, we will stay on something closed but greener." [Sutton - Interview of insider - serie 4]

6.1. "We defined a target of customers [...] They proposed tourist structures. I had good knowledge of them. I helped him to get in touch." [Sutton - Interview of insider - serie 4]

6.2. "Now we are crafting a service dedicated to animation, with its own budget, its own space directly attached to me [the top management]." [Sutton - Interview of insider - serie 4]

6.2. "The name of this new service will be defined very soon. I asked him to make propositions and test them with his fellows." [Sutton - Interview of newcomer - serie 4].

6.3. "I told the accountant that he will now be in direct contact with Luca. [...] I help him [Luca] to develop relationships with new partners: town halls, schools and colleges, and holiday villages. We are working on commercial propositions of team building animations for large companies. I have mobilized my network." [Sutton - Interview of newcomer - serie 4]

6.3. "I will no longer work with my colleagues on fieldwork. I will work more closely with the boss and less with them." [Sutton - Interview of newcomer - serie 4]

7.1. "He gave me a budget to work on the development of the [animation] project. It was not a large amount, but it was the first step in testing. However, the most important aspect is the time that I had to develop the idea." [Sutton - Interview of newcomer - serie 4]

7.2. "I presented the results of my market study to them. They challenged me, but that was the purpose of the meeting. Obviously, we have been reworking things since then, but it was at that moment that they took the measure of the project and gave me a green light to test it." [Sutton Interview of newcomer - serie 4]

7.2. "We had already discussed his idea, but at this meeting, it was clearly a test. We wanted to assess the project and take a decision. We challenged him even the accountant was here? [Sutton - Interview of insider - serie 4

8.1. "I observed my colleague to understand why he was more precise than me while cutting wood." [Sutton - Interview of newcomer - serie 2]

8.2. John explains to me that he was searching for documents to have more information because he did not understand how the team came to make this technical proposal. [Covax - Informal discussion at the third observation]

8.3. "The software is very different from the one I was using. Could I ask you some questions?" [Covax - Observation - serie 2]

9.1. "Luca confirmed to me that he was really following his colleague's advice because he realized that it works well to be more precise in his gestures. He was happy to see that I had noticed it, and he hoped his colleagues noticed it too." [Sutton - Informal discussion in the third period of observation]

9.2. "I draw inspiration from Eliatt because he is really good in team work. He knows how to talk about his work in order to make himself understood by everyone. Everyone is an expert in their own area and it is sometimes difficult to make oneselt understood. [...] I'm trying to perform like him." [Covax Interview of newcomer - serie 4]

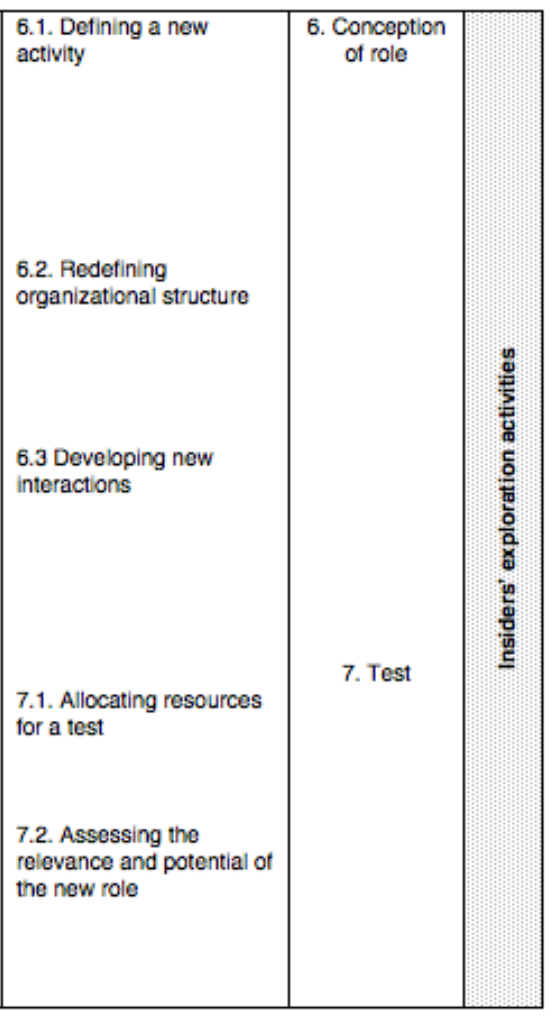

8.1. Observing how colleagues do things and 8. Information behave

8.2. Searching out and consulting documents

8.3. Asking questions and looking for advices

9.1. Following advices and instructions

9. Acting as a follower

seeking
9.2. Imitating insiders' practices and behaviors 
10.1 "Is it really ind spensable to carry earplugs? I'm not used to this and I do not like the feeling of hearing only the beating of my heart." [Observation at Sutton - serie 1 Newcomer]

10.2. "I told them that it was a really bad idea for undergrowth during nesting time [...] we disrupt the fauna." [Sutton - Interview of newcomer - serie 3]

11.1. "I told them that we can organize our activities differently and do the same things, but after the nesting time. We could do other activities during summer time and accomplish this work during the winter." [Sutton - Interview of newcomer - serie 3]

11.1. "When the boss talked to me that we could create a new service in line with the promotion of the ecology, I identified something fun to target new customers and make them more aware of environmental issues." [Sutton - Interview of newcomer - serie 4].

11.2. John explains to his colleague that a document for sharing tools can save them time. He shows his colleague an online tree tool. The colleague answers and says that it's interesting. John continues his demonstration. He asks, "Do you think that we can propose it to the boss?" [Covax - coservation serie 4 - newcomer!

11.2. "Putting ecology in our business is going a step forward. He has strong convictions and I think that we can no longer work in the forestry business nowadays without that. He is right to push us in this direction." [Sutton - Interview of manager - serie 4]

12.1. "He does not have the same approach of the organization of a logging site. He stores the wooden-cuts once everything has been cut. We store as we go. If the job lasts 3 days, we leave it clean at the end of each day." [Sutton - Interview of insider - serie 3]

12.2. "He is slightly familiar with customers. We must stay on a professional language register." [Covax Interview with insider - serie 4]

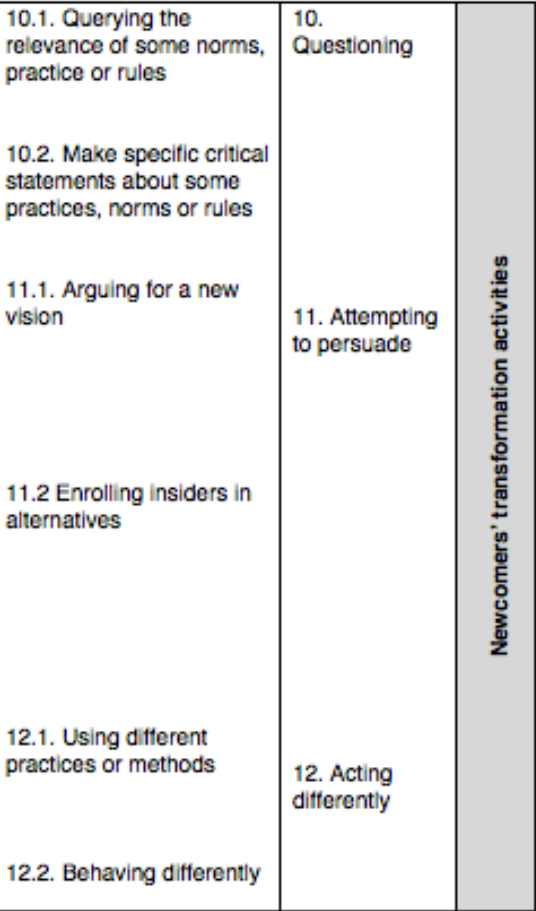


Appendix 2: Correlations and descriptive statistics

\section{First-order themes}

\begin{tabular}{|r|c|}
\multicolumn{1}{c}{$\begin{array}{c}\text { Number of } \\
\text { occurrences }\end{array}$} & $\%$ \\
\hline 157 & 8.91 \\
\hline 123 & 6.98 \\
\hline 92 & 5.22 \\
\hline 32 & 1.81 \\
\hline 11 & 0.62 \\
\hline 210 & 11.9 \\
\hline 10 & 0.56 \\
\hline
\end{tabular}

3.3. Giving specific tasks that allow collaboration with colleagues and peers

$61 \quad 3.46$

4.1. Pointing out errors or faux pas

$70 \quad 3.97$

4.2. Requiring the newcomer to adjust

\begin{tabular}{l|l}
15 & 0.9
\end{tabular}

4.3. Monitoring compliance and putting it under scrutiny $116 \quad 6.8$

5.1. Discussing criticisms and testing ideas on some aspects of the role

$140 \quad 7.9$

5.2. Accepting adjustments and redefining some aspects associated with the role

6.1. Defining a new activity

$41 \quad 2.32$

6.2. Redefining organizational structure

$20 \quad 1.13$

6.3. Developing new interactions

$21 \quad 1.19$

7.1. Allocating resources for a test

$10 \quad 0.56$

7.2. Assessing the relevance and potential of the new role

\begin{tabular}{l|l}
16 & 0.9
\end{tabular}

8.1. Observing how colleagues do things and behave

$102 \quad 5.8$

8.2. Searching and consulting documents

$47 \quad 2.66$

8.3. Asking questions and looking for advice

$111 \quad 6.3$

9.1. Following advice and instructions

$18 \quad 1.02$

9.2. Imitating insiders' practices and behaviors

$15 \quad 0.85$

10.1. Querying the relevance of norms, practices or rules

$39 \quad 2.21$

10.2. Making specific critical statements about some norms, practices or rules

11.1. Arguing for a new vision

$68 \quad 3.86$

11.2. Enrolling insiders in new alternatives

$11 \quad 0.62$

12.1. Using different practices or methods

\begin{tabular}{l|l}
46 & 2.61
\end{tabular}




\section{REFERENCES}

Allen, N.J. \& Meyer, J.P. (1990). The Measurement and Antecedents of Affective, Continuance and Normative Commitment to the Organization. Journal of Occupational Psychology, 63(1), 1-18.

Ashford, S. \& Black, S. (1996). Proactivity During Organizational Entry: The Role of Desire for Control. Journal of Applied Psychology, 81(2), 199.

Ashford, S. \& Nurmohamed, S. (2012). From Past to Present and into the Future: A Hitchhiker's Guide to the Socialization Literature. In C. Wanberg (Ed.), The Oxford Handbook of Organizational Socialization (pp. 8-24). New York, NY: Oxford University Press.

Ashforth, B. (2012). The Role of Time in Socialization Synamics. In C. Wanberg (Ed.), The Oxford Handbook of Organizational Socialization (pp. 161-186). New York, NY: Oxford University Press.

Ashforth, B., Harrison, S. \& Sluss, D. (2014). Becoming: The Interaction of Socialization and Identity in Organizations Over Time. Time and Work, 1, 11-39.

Ashforth, B., Sluss, D. \& Saks, A.M. (2007). Socialization Tactics, Proactive Behavior, and Newcomer Learning: Integrating Socialization Models. Journal of Vocational Behavior, 70(3), 447-462.

Atkinson, J. \& Storey, D.J. (2016), Employment, the Small Firm and the Labour Market, London, UK: Routledge.

Bargues, E. \& Perrot, S. (2016). Pourquoi n'est-il pas resté? Comprendre les processus et les résultats de l'intégration des nouvelles recrues dans les PME. @GRH, 20(3), 43-79.

Battilana, J. (2011). The Enabling Role of Social Position in Diverging from the Institutional Status Quo: Evidence from the UK National Health Service. Organization Science, 22(4), 817-834.

Battilana, J., Leca, B. \& Boxenbaum, E. (2009). How Actors Change Institutions: Towards a Theory of Institutional Entrepreneurship. The Academy of Management Annals, 3(1), 65-107.

Bauer, T., Bodner, T., Erdogan, B., Truxillo, D. \& Tucker, J. (2007). Newcomer Adjustment during Organizational Socialization: A Meta-analytic Review of Antecedents, Outcomes, and Methods. Journal of Applied Psychology, 92(3), 707.

Bauer, T.N. \& Erdogan, B. (2012). Organizational Socialization Outcomes: Now and into the Future. In C. Wanberg (Ed.), The Oxford Handbook of Organizational Socialization (pp. 97-112). New York, NY: Oxford University Press.

Bauer, T.N., Erdogan, B. \& Taylor, S. (2012). Creating and Maintaining Environmentally Sustainable Organizations: Recruitment and Onboarding. In S. Jackson, D. Ones \& S. Dilchert (Eds.), Managing Human Resources for Environmental Sustainability (pp. 222-240). New York, NY: Jossey-Bass/Wiley.
Bauer, T.N., Morrison, E.W. \& Callister, R.R. (1998). Research in Personnel and Human Resource Management, In G.R. Ferris K.M. Rowland (Eds.), Research in Personnel and Human Resource Management (pp. 149-214). Greenwich, CT: Elsevier.

Canales, R. (2012). The Stranger as Friend: Loan Officers and Positive Deviance in Microfinance. In K. Golden-Biddle \& J. Dutton (Eds.), Using a Positive Lens to Explore Social Change and Organizations: Building a Theoretical and Research Foundation (pp. 31-45). New York, NY: Routledge.

Cardon, M.S. \& Stevens, C.E. (2004). Managing Human Resources in Small Organizations: What do we Know? Human Resource Management Review, 14(3), 295-323.

Clark, S.M., Gioia, D.A., Ketchen, D.J. \& Thomas, J.B. (2010). Transitional Identity as a Facilitator of Organizational Identity Change during a Merger. Administrative Science Quarterly, 55(3), 397-438.

Cooper-Thomas, H., Anderson, N. \& Cash, M. (2011). Investigating Organizational Socialization: A Fresh Look at Newcomer Adjustment Strategies. Personnel Review, 41(1), 41-55.

Cooper-Thomas, H.D. \& Wilson, M.G. (2011). Influences on Newcomers' Adjustment Tactic Use. International Journal of Selection and Assessment, 19(4), 388-404.

Corbin, J. \& Strauss, A. (2007), Qualitative Research (Third ed.), London, UK: Sage.

Currie, G. \& Spyridonidis, D. (2016). Interpretation of Multiple Institutional Logics on the Ground: Actors' Position, their Agency and Situational Constraints in Professionalized Contexts. Organization Studies, 37(1), 77-97.

Dacin, M.T., Munir, K. \& Tracey, P. (2010). Formal Dining at Cambridge Colleges: Linking Ritual Performance and Institutional Maintenance. Academy of Management Journal, 53(6), 1393-1418.

Delacour, H. \& Leca, B. (2011). The Decline and Fall of the Paris Salon: A Study of the Deinstitutionalization Processs of a Field Configuring Event in the Cultural Activities. M@n@gement, 14(1), 436-466.

DiMaggio, P.J. (1988). Interest and Agency in Institutional Theory. Institutional Patterns and Organizations: Culture and Environment, 1, 3-22.

Eisenhardt, K.M. \& Graebner, M.E. (2007). Theory Building from Cases: Opportunities and Challenges. Academy of Management Journal, 50(1), 25-32.

Ellis, A.M., Bauer, T.N. \& Erdogan, B. (2014). New Employee Organizational Socialization. In J. Gruzec \& P. Hastings (Eds.), Handbook of Socialization: Theory and Research (pp. 301-322). New York, NY: Guilford Press.

Ellis, A.M., Bauer, T.N., Mansfield, L.R., Erdogan, B., Truxillo, D.M. \& Simon, L.S. (2015). Navigating Uncharted Waters Newcomer Socialization through the Lens of Stress Theory. Journal of Management, 41(1), 203-235. 
Emirbayer, M. \& Mische, A. (1998). What is Agency? American Journal of Sociology, 103(4), 962-1023.

Erdogan, B., Bauer, T.N., Truxillo, D.M. \& Mansfield, L. (2012). Whistle while you Work: A Review of the Life Satisfaction Literature. Journal of Management, 38(4), 1038-1083.

Feldman, D. (1976). A Contingency Theory of Socialization. Administrative Science Quarterly, 21(3), 433-452.

Feldman, D. (1981). The Multiple Socialization of Organization Members. Academy of Management Review, 6(2), 309-318.

Feldman, M.S. \& Orlikowski, W.J. (2011). Theorizing Practice and Practicing Theory. Organization Science, 22(5), 1240-1253.

Gioia, D.A., Corley, K.G. \& Hamilton, A.L. (2012). Seeking Qualitative Rigor in Inductive Research Notes on the Gioia Methodology. Organizational Research Methods, 16(1), 15-31.

Glaser, B. \& Strauss, A. (1967), The Discovery of Grounded Theory, London, UK: Weidenfeld and Nicholson.

Gray, C. (2006). Absorptive Capacity, Knowledge Management and Innovation in Entrepreneurial Small Firms. International Journal of Entrepreneurial Behavior \& Research, 12(6), 345-360.

Hansen, T. \& Levine, J.M. (2009). Newcomers as Change Agents: Effects of Newcomers' Behavioral Style and Teams' Performance Optimism. Social Influence, 4(1), 46-61.

Hayton, J.C. (2003). Strategic Human Capital Management in SMEs: An Empirical Study of Entrepreneurial Performance. Human Resource Management, 42(4), 375-391.

Hayton, J.C. Hornsby, J.S. \& Bloodgood, J. (2013). The Contribution of HRM to Corporate Entrepreneurship: A Review and Agenda for Future Research.M@n@gement, 16(4), 381-409.

Heaphy, E. (2013). Repairing Breaches with Rules: Maintaining Institutions in the Face of Everyday Disruptions. Organization Science, 24(5), 1291-1315

Heneman, R. \& Tansky, J. (2002). Human Resource Management Models for Entrepreneurial Opportunity: Existing Knowledge and New Directions. In J.A. Katz \& T.M. Welbourne (Eds.), Managing People in Entrepreneurial Organiztions (pp. 55-81). Bingley, UK: Emerald Group Publishing Limited.

Heneman, R., Tansky, J. \& Camp, M. (2000). Human Resource Management Practices in Small and Medium-Sized Enterprises: Unanswered Questions and Future Research Perspectives. Entrepreneurship: Theory and Practice, 25(1), 11-11.

Jones, G.R. (1986). Socialization Tactics, Self-efficacy, and Newcomers' Adjustments to Organizations. Academy of Management Journal, 29(2), 262-279.

Kammeyer-Mueller, J.D., Livingston, B.A. \& Liao, H. (2011). Perceived Similarity, Proactive Adjustment, and Organizational Socialization. Journal of Vocational Behavior, 78(2), 225-236.
Klein, H.J. \& Heuser, A.E. (2008). The Learning of Socialization Content: A Framework for Researching Orientating Practices. Research in Personnel and Human Resources Management, 27(8), 279-336.

Klein, H.J., Polin, B. \& Leigh Sutton, K. (2015). Specific Onboarding Practices for the Socialization of New Employees. International Journal of Selection and Assessment, 23(3), 263-283.

Klein, H.J. \& Weaver, N A. (2000). The Effectiveness of an Organizational Level Orientation Training Program in the Socialization of New Hires. Personnel Psychology, 53(1), 47-66.

Langley, A. (1999). Strategies for Theorizing from Process Data. Academy of Management Review, 24(4), 691-710.

Lawrence, T., Leca, B. \& Zilber, T. (2013). Institutional Work: Current Research, New Directions and Overlooked Issues. Organization Studies, 34(8), 1023-1033.

Lawrence, T. \& Suddaby, R. (2006). Institutions and Institutional Work. In S. Clegg, C. Hardy, T. Lawrence W. Nord (Eds.), The SAGE Handbook of Organization Studies (pp. 215). London, UK: Sage.

Lawrence, T., Suddaby, R. \& Leca, B. (2009), Institutional Work: Actors and Agency in Institutional Studies of Organizations, Cambridge: Cambridge University Press.

Lawrence, T., Suddaby, R. \& Leca, B. (2011). Institutional Work: Refocusing Institutional Studies of Organization. Journal of Management Inquiry, 20(1), 52-58.

Levine, J.M., Moreland, R.L. \& Hausmann, L.R. (2005). Managing Group Composition: Inclusive and Exclusive Role Transitions. In D.Abrams, M.A Hogg \& J.M Marques (Eds.), The Social Psychology of Inclusion and Exclusion (pp.137-160). New York, Hove : Psychology Press.

Nelson, D.L. (1987). Organizational Socialization: A Stress Perspective. Journal of Organizational Behavior, 8(4), 311-324.

Nicolini, D. (2012), Practice Theory, Work, and Organization: An Introduction, Oxford: Oxford University Press.

Nifadkar, S.S. \& Bauer, T.N. (2016). Breach of Belongingness: Newcomer Relationship Conflict, Information, and Task-Related Outcomes during Organizational Socialization. Journal of Applied Psychology, 101(1), 1.

Østerlund, C. \& Carlile, P. (2003). How Practice Matters: A Relational View of Knowledge Sharing. In M Huysman, E. Wenger \& V. Wulf (Eds.), Communities and Technologies (pp. 1-22). Dordrecht: Springer.

Perrot, S., Bauer, T.N., Abonneau, D., Campoy, E., Erdogan, B. \& Liden, R.C. (2014). Organizational Socialization Tactics and Newcomer Adjustment: The Moderating Role of Perceived Organizational Support. Group \& Organization Management, 39(3), 247-273.

Rollag, K. \& Cardon, M. (2003). How much is Enough? Comparing Socialization Experiences in Start-up versus Large Organizations. Unpublished paper presented at the Babson-Kaufman Entrepreneurial Research Conference, Boulder, CO. 
Rollag, K., Parise, S. \& Cross, R. (2005). Getting New Hires up to Speed Quickly. MIT Sloan Management Review, 46(2), 35.

Rouleau, L. \& Balogun, J. (2011). Middle Managers, Strategic Sensemaking, and Discursive Competence. Journal of Management Studies, 48(5), 953-983.

Saks, A. \& Gruman, J. (2012). Getting Newcomers on Board: A Review of Socialization Practices and Introduction to Socialization Resources Theory. In C. Wanberg (Ed.), The Oxford Handbook of Organizational Socialization (pp. 27-55). New York, NY: Oxford University Press.

Saks, A., Gruman, J. \& Cooper-Thomas, H. (2011). The Neglected Role of Proactive Behavior and Outcomes in Newcomer Socialization. Journal of Vocational Behavior, 79(1), 36-46.

Saks, A., Uggerslev, K.L. \& Fassina, N.E. (2007). Socialization Tactics and Newcomer Adjustment: A Meta-Analytic Review and Test of a Model. Journal of Vocational Behavior, 70(3), 413-446.

Schein, E.H. (1978), Career Dynamics: Matching Individual and Organizational Needs, Reading, MA: Addison-Wesley.

Seo, M.-G. \& Creed, W.D. (2002). Institutional Contradictions, Praxis, and Institutional Change: A Dialectical Perspective. Academy of Management Review, 27(2), 222-247.

Simpson, B. (2009). Pragmatism, Mead and the Practice Turn. Organization Studies, 30(12), 1329-1347.

Smets, M. \& Aristidou, A. (2017). Towards a PracticeDriven Institutionalism. In R. Greenwood, C. Oliver, T. Lawrence \& R. Meyer (Eds.), The Sage Handbook of Organizational Institutionalism (pp. 365). London, UK: Sage.

Smets, M. \& Jarzabkowski, P. (2013). Reconstructing Institutional Complexity in Practice: A Relational Model of Institutional Work and Complexity. Human Relations, 66(10), 1279-1309.

Solinger, O.N., van Olffen, W., Roe, R.A. \& Hofmans, J. (2013). On Becoming (Un)committed: A Taxonomy and Test of Newcomer Onboarding Scenarios. Organization Science, 24(6), 1640-1661.

Storey, D. (2016), Understanding the Small Business Sector, London, UK: Routledge.

Strauss, A. \& Corbin, J. (1998), Basics of Qualitative Research: Procedures and Techniques for Developing Grounded Theory, Thousand Oaks, CA: Sage.

Taupin, B. (2012). The More Things Change... Institutional Maintenance as Justification Work in the Credit Rating Industry. M@n@gement, 15(5), 529-562.

Vancouver, J.B. \& Warren, M.A. (2012). This is How We Do Research Around Here: The Socializing Methodological and Measurement Issues. In C. Wanberg (Ed.), The Oxford Handbook of Organizational Socialization (pp. 187-211). New York, NY: Oxford University Press.

Van Maanen, J. \& Schein, E. (1979). Toward a Theory of Organizational Socialization. Research in Organizational Behavior, 1, 209-264.
Varis, M. \& Littunen, H. (2010). Types of Innovation, Sources of Information and Performance in Entrepreneurial SMEs. European Journal of Innovation Management, 13(2), 128-154.

Wanberg, C. (2012), The Oxford Handbook of Organizational Socialization, New York, NY: Oxford University Press.

Wanberg, C. \& Choi, Y. (2012). Moving Forward: Next Steps for Advancing the Research and Practice of Employee Socialization. In C. Wanberg (Ed.), The Oxford Handbook of Organizational Socialization (pp. 339). New York, NY: Oxford University Press.

Wanous, J.P. (1980), Organizational Entry: Recruitment, Selection, and Socialization of Newcomers, London, UK: Prentice Hall.

Wesson, M.J. \& Gogus, C.I. (2005). Shaking Hands with a Computer: An Examination of Two Methods of Organizational Newcomer Orientation. Journal of Applied Psychology, 90(5), 1018.

Zilber, T. (2002). Institutionalization as an Interplay Between Actions, Meanings, and Actors: The Case of a Rape Crisis Center in Israel. Academy of Management Journal, 45(1), 234-254.

Zilber, T. (2009). Institutional Maintenance as Narrative Acts. In T. Lawrence, R. Suddaby \& B. Leca (Eds.), Institutional Work: Actors and Agency in Institutional Studies of Organizations (pp. 205-235). Cambridge: Cambridge University Press.

Zucker, L. (1988). Where Do Institutional Patterns Come From? Organizations as Actors in Social Systems. Institutional Patterns and Organizations: Culture and Environment, 20(3), 23-49. 
Emilie Bargues is assistant professor of organizational theory and intrapreneurship at ESC Clermont-Ferrand. Her research focuses on organizational socialization and innovation. She also works on corporate governance issues and practices.

Bertrand Valiorgue is professor of strategy and corporate governance at Clermont Auvergne University. He holds the Alter-Governance Chair and has expertise in the governance of cooperatives.

Acknowledgments: The authors extend their warmest thanks to Laure Cabantous for her support and challenging comments. We also want to thank our two reviewers for their useful remarks and advice. 